\title{
Biographies of the Authors
}

\author{
CHARLES ROSEN
}

Pianist Charles Rosen (1927-20I2) was a child prodigy, entering the Juilliard School of Music when he was six years old. At eleven, he became a pupil of the celebrated pianist Moriz Rosenthal, himself a former student of Franz Liszt, and began his international career.

A well-known musicologist and lecturer at Harvard (the Norton Lectures), he also taught at Oxford University and the University of Chicago. He is the author of numerous books and articles on music including The Frontiers of Meaning: Three Informal Lectures on Music and The Romantic Generation (the Charles Eliot Norton Lectures). The Classical Style received the National Book Award and was awarded the Edison Prize for his body of work. He 
held honorary doctorates from the universities of Cambridge, Leeds, Durham, Bristol, and Trinity College, Dublin. President Obama awarded him the National Humanities Medal on February I3, 2012.

\section{CATHERINE TEMERSON}

Catherine Temerson (1944-2015) was the literary director of the Ubu Repertory Theater of New York. She held a master's degree in Russian literature from Harvard University and a PhD in comparative literature from New York University. Completely bilingual in English and French, she published Hollywood, petite histoire d'un grand empire and translations into English of a number of works, including books by Elie Wiesel, Amin Maalouf, and André ComteSponville. Her father, Léon Temerson, was one of the first violins of the New York Philharmonic Orchestra and the concertmaster of the New York Philharmonic Chamber Ensemble. 


$$
\begin{aligned}
& \text { The Joy of Playing, } \\
& \text { the Joy of Thinking }
\end{aligned}
$$


